\title{
A simplified table for staging embryos of the pipid frog Pipa arrabali
}

\author{
OLÍVIA G.S. ARAÚJO ${ }^{1}$, CÉLIO F.B. HADDAD ${ }^{1}$, HÉLIO R. DA SILVA ${ }^{2}$ and LOURDES A. PUGENER ${ }^{3}$ \\ ${ }^{1}$ Departamento de Zoologia, Instituto de Biociências, Universidade Estadual Paulista, \\ Caixa Postal 199, 13506-970 Rio Claro, SP, Brasil \\ ${ }^{2}$ Departamento de Biologia Animal, Instituto de Biologia, Universidade Federal Rural do \\ Rio de Janeiro, Caixa Postal 74524, 23851-970 Seropédica, RJ, Brasil \\ ${ }^{3}$ Facultad de Ciencias Exactas y Naturales, Universidad Nacional de La Pampa, CP 6300 Santa Rosa, La Pampa, Argentina
}

Manuscript received on September 2, 2015; accepted for publication on March 1, 2016

\begin{abstract}
Pipa is a Neotropical genus of frogs that dwell in freshwater environments. It includes four species that lack free-swimming larvae (P. aspera, P. arrabali, P. pipa, and P. snethlageae) and three with tadpoles ( $P$. carvalhoi, P. myersi, and P. parva). Developmental tables such as the one proposed by Nieuwkoop and Faber might be useful for Pipa species with tadpoles. However, for the other Pipa species, to determine stages by this table or by any of the tables already prepared for frogs without tadpoles (e.g., Crinia nimbus, Eleutherodactylus coqui, and Oreobates barituensis) is impossible. By using embryonic, juvenile, and subadult specimens, we generated a staging table for $P$. arrabali, from the moment limb buds were first observed until birth, based on diagnostic features such as snout-vent length; growth, morphology, and reabsorption of the external tail; growth and differentiation of fore and hind limbs; development of intestine and vent tube; position of the angle of the mouth relative to nostrils and eyes; and color of preserved individuals. Based on these observations, we discuss some noteworthy traits (e.g., posture of hands and feet). We also compare the pattern of development of $P$. arrabali with that of other anuran species (with and without tadpoles).
\end{abstract}

Key words: Amphibia, Anura, development, morphology, Pipidae.

\section{INTRODUCTION}

The conventional idea of frog development is based on the reproductive mode of the so-called 'typical' anurans such as Rana, which is characterized by large clutches of small aquatic eggs and aquatic exotrophic larvae. Anurans, however, exhibit an extraordinary diversity in reproductive patterns including, among others, the bypass of a free-living

Correspondence to: Olívia G.S. Araújo

E-mail: oliviaaraujo@gmail.com larval stage. Examples of this reproductive mode are found amongst brachycephalids (Pombal Jr et al. 1994), eleutherodactylids (Townsend and Stewart 1985), hemiphractids (Del Pino and Escobar 1981); pipids (Trueb and Cannatella 1986, Fernandes et al. 2011), and rhacophorids (Kerney et al. 2007). In the Neotropical pipid frogs of the genus Pipa, small clutches of eggs develop in brood chambers temporarily formed in the skin of female's back (Rabb and Rabb 1960, Trueb and Cannatella 1986, Fernandes et al. 2011). The eggs hatch as tadpoles 
that complete their development in a pond in $P$. carvalhoi, P. myersi, and P. parva (Fernandes et al. 2011, Trueb and Cannatella 1986). In these species the eggs are relatively small (Garda et al. 2006). On the contrary, eggs are large and yolky in $P$. aspera, P. arrabali, P. pipa, and $P$. snethlageae (Trueb and Cannatella 1986, Garda et al. 2006, Wells 2010), and birth occurs after metamorphosis is completed (Rabb and Rabb 1960, Trueb and Cannatella 1986, Trueb et al. 2000). Of these, $P$. arrabali, commonly known as Small Surinam Toad, Arrabal's Suriname Toad, or Rana de Celdillas Guayanesa, is the only species in the genus that occurs in ephemeral freshwater ponds not only at elevations inferior to $450 \mathrm{~m}$, like all other species, but also at $860 \mathrm{~m}$, in the tropical moist lowland of Guyana, Suriname, eastern Venezuela, and northern and central Brazil (Buchacher 1993, Frost 2015).

Several preceding studies have proposed tables of development for staging anuran embryos and larvae (e.g., Taylor and Kollros 1946, Nieuwkoop and Faber 1956, Gosner 1960, Fabrezi et al. 2009), most of which apply to species that have tadpoles. However, these tables are less useful for staging embryos that complete their development as nonfree living larvae because their external morphology deviates markedly from that of aquatic larvae after neurulation. On the other hand, the tables created for staging egg-brooding anurans, e.g., Gastrotheca riobambae (Del Pino and Escobar 1981) or anurans that put terrestrial eggs and lack free-swimming larval stages, e.g., Crinia nimbus (Mitchell and Swain 1996), Eleutherodactylus coqui (Townsend and Stewart 1985) and Oreobates barituensis (Goldberg et al. 2012), are species-specific and cannot be applied to Pipa. Likewise, the simplified external description of a few specimens of $P$. pipa by Parker (1876) and Ridewood (1897), and the staging of embryos of the same species based on size by Trueb et al. (2000) render comparisons difficult to make.

Herein we have designed a staging table for embryos of Pipa arrabali in their later stages of development-that is, from the moment limb buds are first observable until birth. We also compared the pattern of embryonic development of $P$. arrabali with that of other anuran species for which data are available.

\section{MATERIALS AND METHODS}

The staging table was created based on observations of the external morphology of 78 preserved embryos and juveniles of Pipa arrabali from Serra do Cachimbo, Novo Progresso, Pará State, Brazil. The specimens were fixed in $10 \%$ formalin in the field and are deposited in the Coleção Herpetológica da Universidade de Brasília (CHUnB). Four embryos were removed from the anterior, middle, and posterior sections of the dorsum of 17 females. The snout-vent length and head width of each embryo were measured under a stereomicroscope with the aid of a caliper (Appendix). Some specimens from each stage were prepared as cleared-and-doublestained skeletons following the methodology by Taylor and Van Dyke (1985). The length of the incubatory period was not determined because brooding females were never collected at the time of amplexus and fertilization, and therefore, the beginning of incubation was unknown.

Development was divided into two periods. The first one included the early stages of development, from the fertilized egg until the stage previous to the emergence of the limb buds. The second period comprised the later stages of development; from the moment limb buds were first observed until birth. The second period (focus of our research) was divided into 11 stages based on easily discernible features that were used as markers. These features met three conditions, they could be detected with minimal ambiguity, were readily identified by examination with a stereomicroscope, and their presence among individuals was invariable.

The anatomical lexicon used herein for external morphology follows Gosner (1960). For the lateral line system we used the terminology 
proposed by Shelton (1970), who developed a naming system based on Xenopus that is more similar to Pipa than that used for other frogs. Descriptions and illustrations were made with the aid of a stereomicroscope equipped with a camera lucida and digital camera.

\section{RESULTS AND DISCUSSION}

Although embryonic development is a continuum (Fig. 1), for comparative purposes we divided this process into early and late development (Periods I and II, respectively). The division between both periods is demarcated by a distinct event, the emergence of the limb buds. The key diagnostic characters of each stage are summarized in Table I; additional traits are provided in Table II.

During the first few stages of development of the second period, some aspects of the embryos of Pipa arrabali resemble a generalized biphasic anuran prior to the initiation of the process of metamorphosis (approximately between Gosner Stages 25-35 and Nieuwkoop and Faber Stages 42-55). The features that contribute to this resemblance include an oblong body, the corner of the mouth rostral to the anterior margin of the eye, and a long and muscular tail. Throughout these stages we also found overall similarities in the sequence of morphological changes that affect the initial development of the hind limbs; i.e., emergence of distally rounded hind limbs during Stage II-1 (about Gosner Stages 26-30; Nieuwkoop and Faber Stages 46-52) and development of a paddle-shaped outline of the foot during Stage II-2 (between Gosner Stages 31-33; Nieuwkoop and Faber Stages 53). The aforementioned embryonic morphology is different from that observed in other anurans that lack a free-living larval stage, such as Eleutherodactylus coqui (Townsend and Stewart 1985, Callery et al. 2001, Elinson 2001). In this species some region develop precociously, displaying what in species with tadpoles would be a mid-metamorphic or even a postmetamorphic morphology.

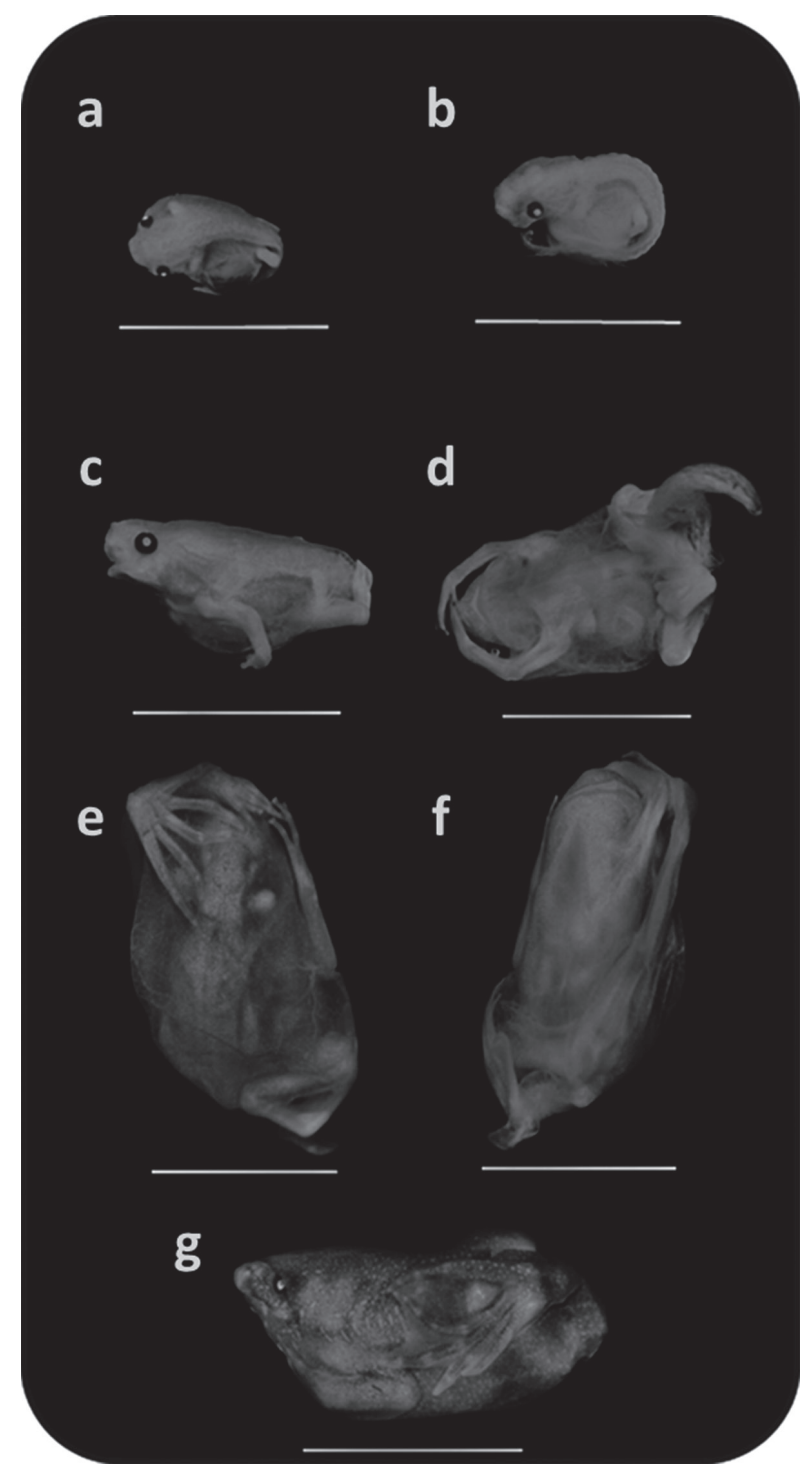

Figure 1 - Pipa arrabali embryos. a: Dorsal view of Stage II-2 (CHUnB 35027-D); b: Left lateral view of Stage II-3 (CHUnB 35055-D); c: Left lateral view of Stage II-5 (CHUnB 35045D); d: Ventral view of Stage II-6 (CHUnB 35019-D); e: Dorsal view of Stage II-10; f: Ventral view of Stage II-10 (CHUnB 35013-D); g: Left lateral view of Stage II-11(CHUnB 35053D). Scale bars $=5 \mathrm{~mm}$

The mouth of the embryo of Pipa arrabali is terminal, transverse, and slit-like (Fig. 2a and 2c), lacking the oral keratinous structures (i.e., jaw sheath and labial teeth) that most tadpoles usually have (Vitt and Caldwell 2014). The same mouth morphology observed in the developing $P$. arrabali is also shared by other species of Pipa (Sokol 1977, 
Pugener et al. 2003), both with and without freeliving larvae. Barbels (= tentacles of Nieuwkoop and Faber 1956) at each corner of the mouth, similar to those found in other extant and extinct pipids such as Silurana, Xenopus, and †Llankibatrakus (Sokol 1977, Baéz and Pugener 2003), are absent.
Barbellae (i.e., the short and slender marginal structures around the mouth of Rhinophrynus, Orton 1943) also are absent. A keratinized eggtooth such as the one present in, for example, Eleutherodactylus (Hardy Jr 1984, Townsend and Stewart 1985) is lacking in P. arrabali.

TABLE I

A simplified table for staging Pipa arrabali embryos based on key diagnostic characters. The correlations of diagnostic characters between this table and the staging tables proposed by Gosner (1960) and Nieuwkoop and Faber (1954) are shown.

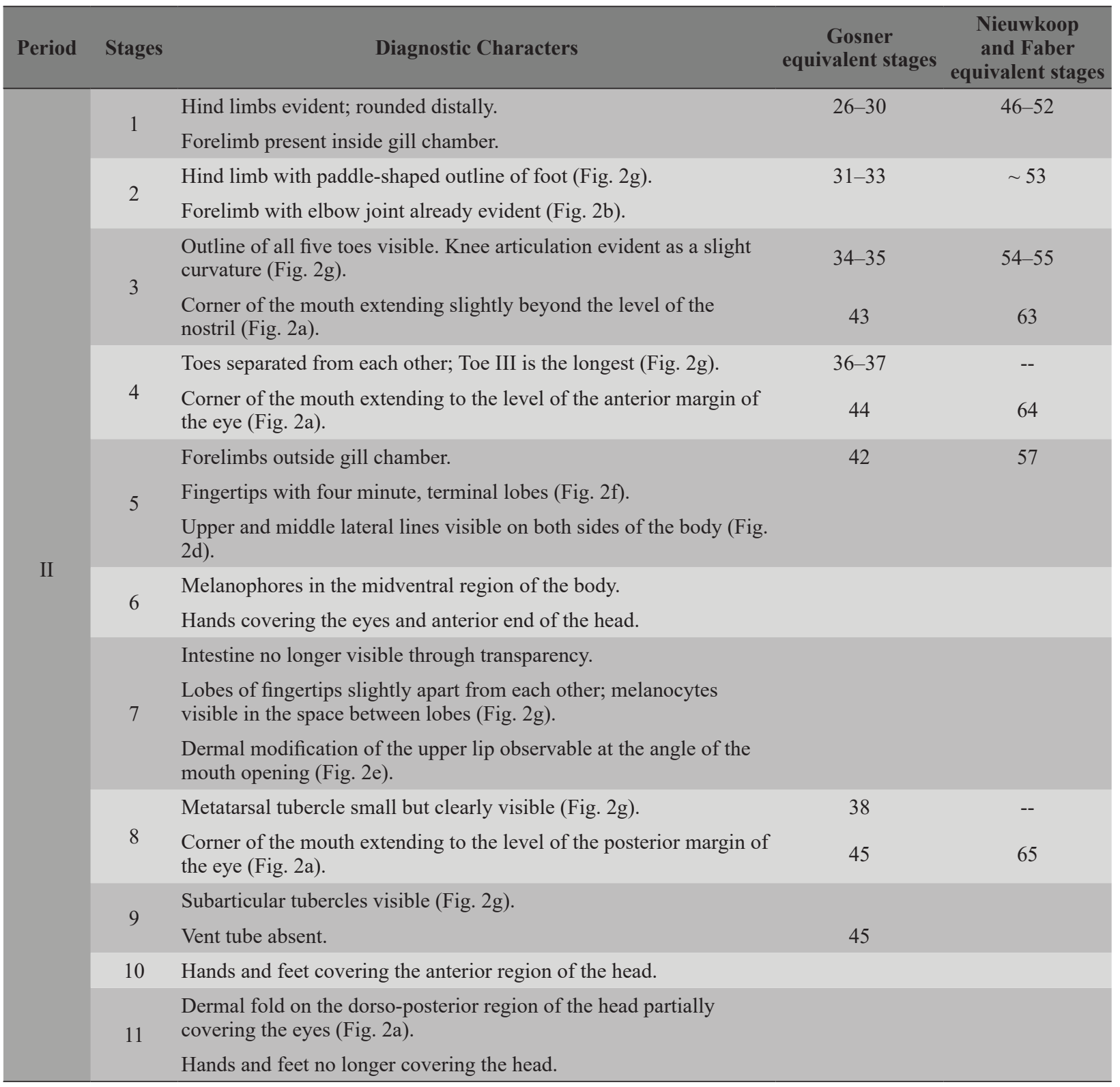




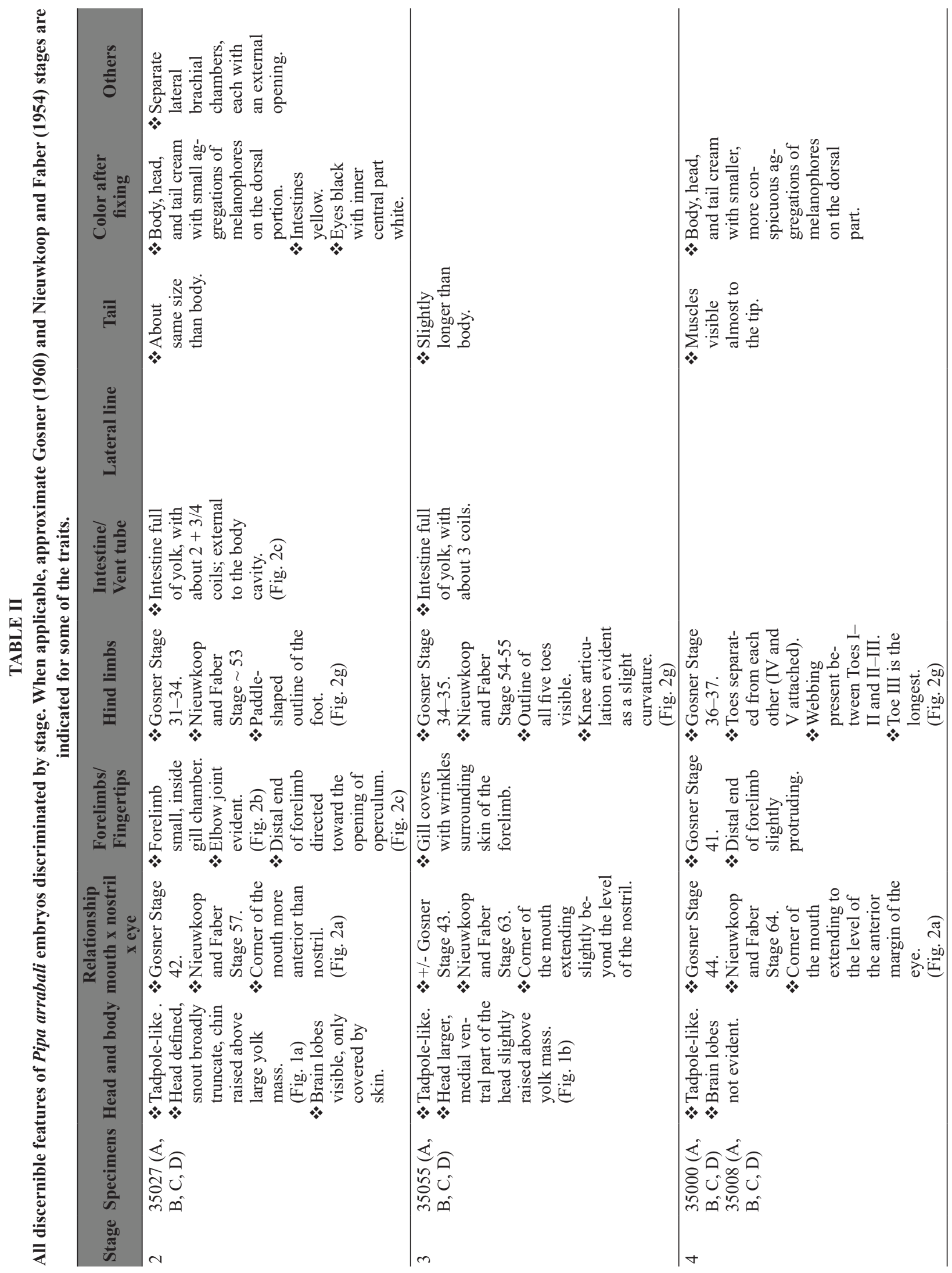




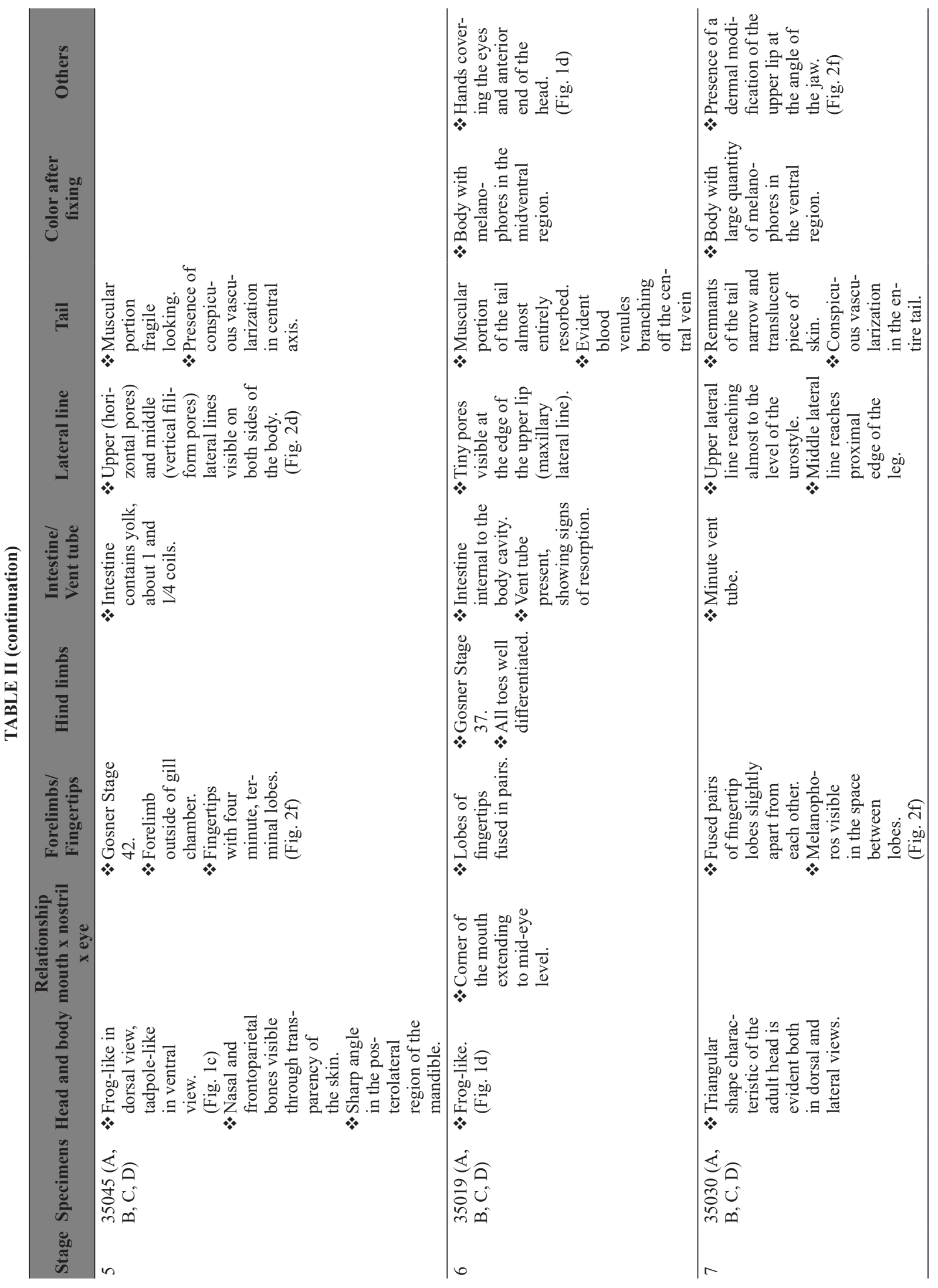



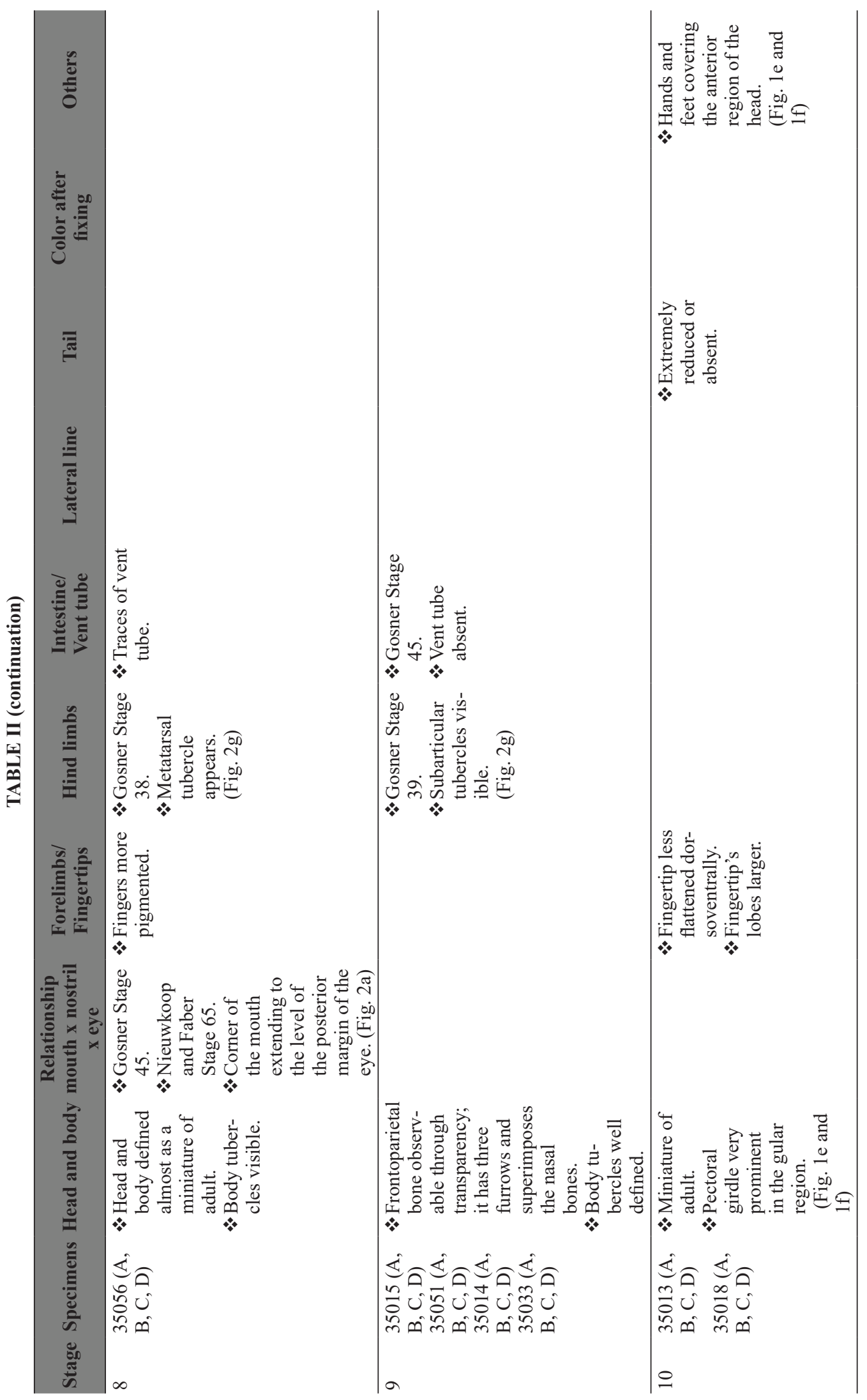


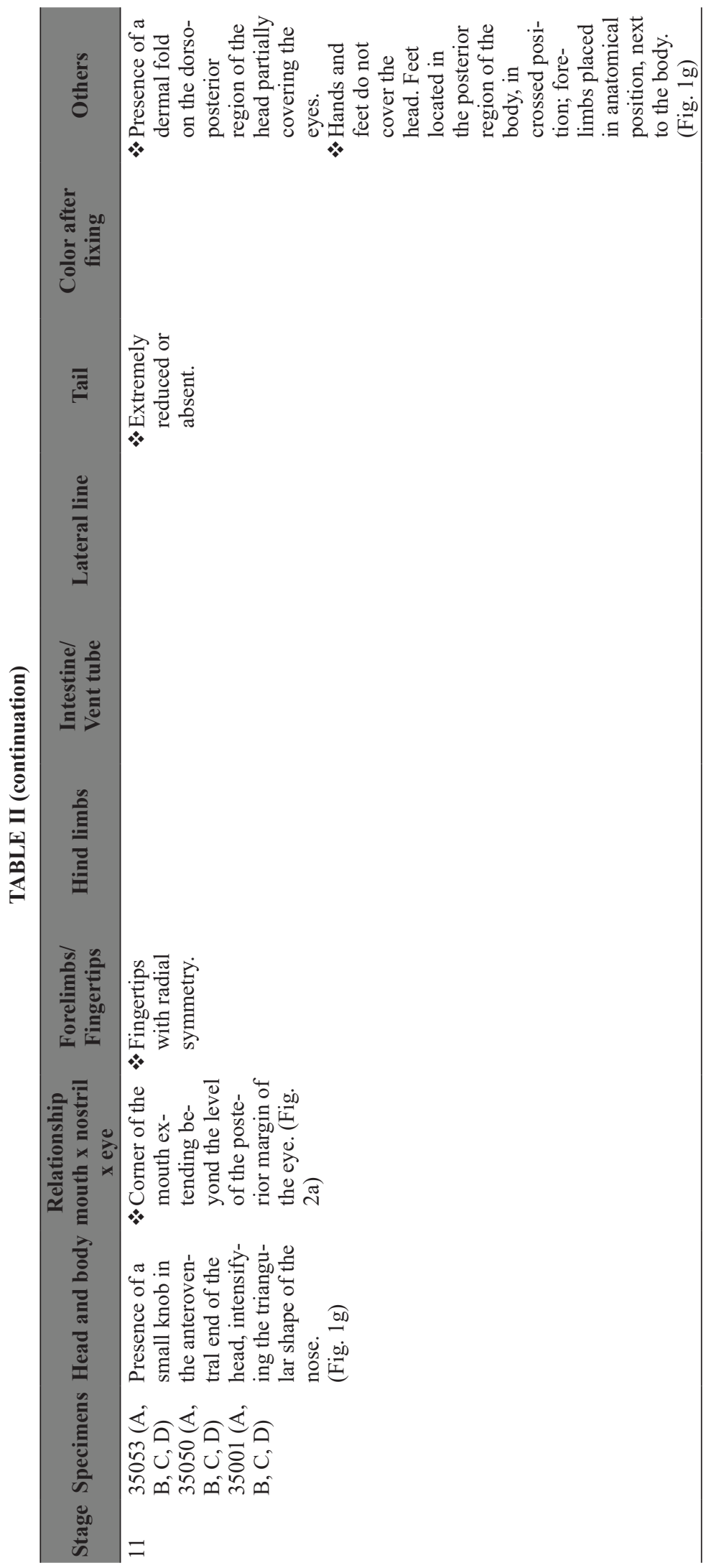




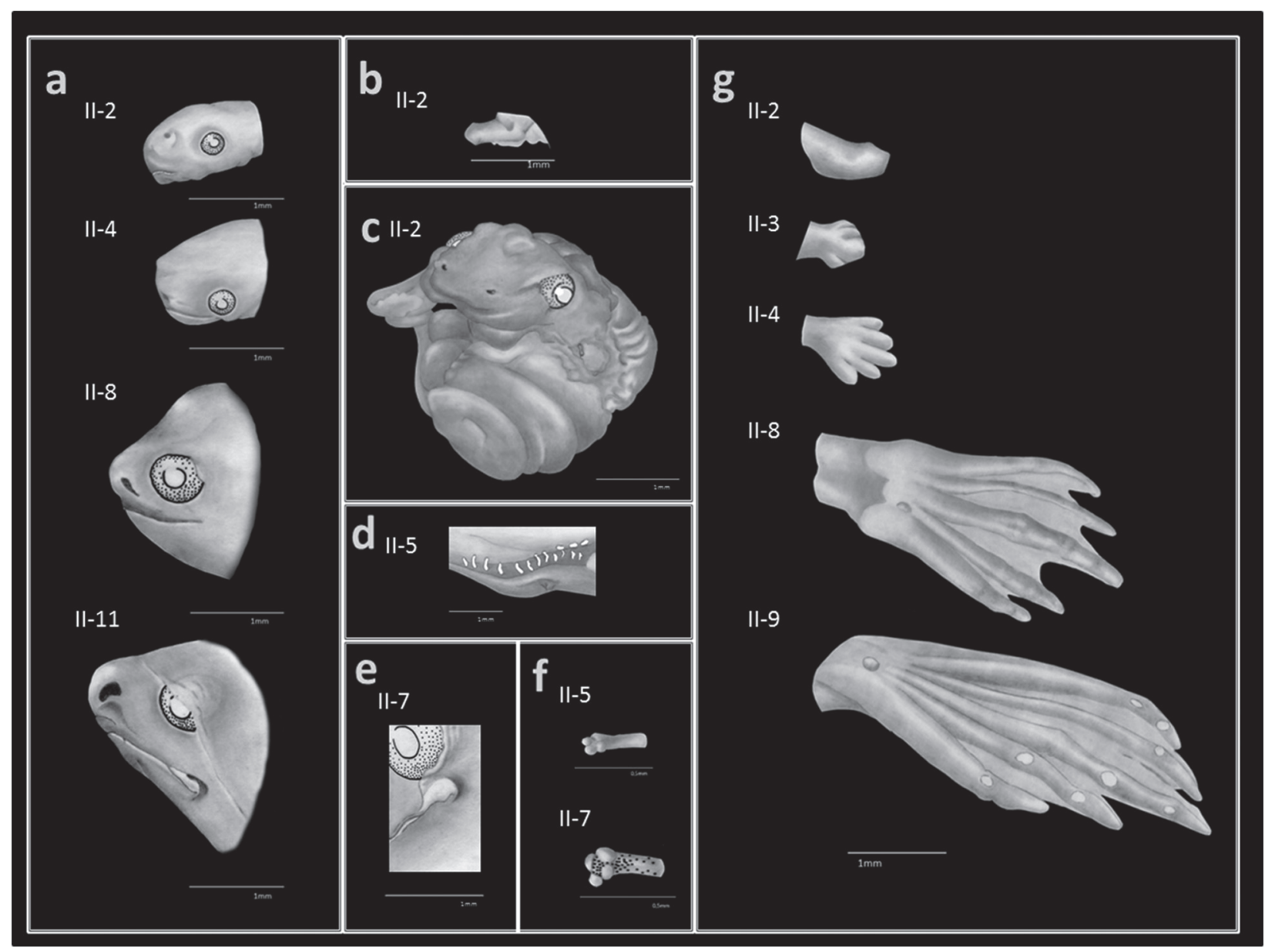

Figure 2 - Camera lucida drawing of Pipa arrabali embryos. a - Left lateral view of the head of Stage II-2 (CHUnB 35027-D), II-4 (CHUnB 35000-D), II-8 (CHUnB 35056-D), and II-11 (CHUnB 35053-D) showing the differences in the position of the angle of the mouth relative to nostrils and eyes; in II-11 also showing the dermal fold covering partially the eye. $\mathbf{b}$ - Lateral view of left forelimb, inside gill chamber, of Stage II-2 (CHUnB 35027-D), showing the elbow joint (in the drawing was omitted the cover skin of the gill chamber, focusing only on the forelimb). c - Fronto-ventral view of Stage: II-2 (CHUnB 35027-D) showing the coiled intestine full of yolk. d - Left lateral view of the trunk, in between arm and leg, of Stage II-5 (CHUnB 35045-D) showing the pores of the upper and middle lateral lines. e - Left lateral view of the mouth of Stage II-7 (CHUnB 35030-D) showing the dermal modification of the upper lip. f - Latero-frontal view of the fingertip morphology of Stages II-5 (CHUnB 35045-D) and II-7 (CHUnB 35030-D). g - Ventral view of the right hind limb of Stages II-2 (CHUnB 35027-D), II-3 (CHUnB 35055-D), II-4(CHUnB 35000-D), II-8 (CHUnB 35056-D), and II-9 (CHUnB 35051-D) showing feet development and differentiation.

In Pipa arrabali there is an early backwards migration (Stage II-8) of the corner of the mouth (to the level of, or posterior to, the posterior margin of the eye) when compared with biphasic species. In the latter, the above-mentioned change occurs close to the end of metamorphosis (e.g., about Gosner Stage 44 in Bombina orientalis and Nieuwkoop and Faber Stage 65 in Xenopus laevis). On the contrary, by Stage II- 8 (four stages before the end of metamorphosis) the external morphology of the head of an embryonic $P$. arrabali is substantially different from its initial appearance, and reminiscent of a late metamorphic stage in biphasic anurans.

Pipa arrabali displays a dermal flange on the upper lip at the angle of the mouth opening by Stage II-7. It consists of a narrow labial pocket surrounding the corner of the mouth, and a simple piece of tissue shaped like a teardrop that partially 
covers over the posterior end of the lower lip (Fig. 2f). This upper lip adornment grows larger by Stage II-8, decreasing in size in the subsequent stage until almost disappearing by the Stage II-10. A dermal modification of the upper lip occurs in the metamorphic stages of all other small species of Pipa, (i.e., P. aspera, P. carvalhoi, P. myersi, and $P$. parva) and persists in the adults, although proportionally smaller (Trueb and Cannatella 1986). Apparently, the same structure occurs in $P$. pipa and $P$. snethlageae, but it is larger and with an irregular edge. All others species of Xenoanura (Olívia G.S. Araújo, personal observation, Trueb and Cannatella 1986) lack adornments on the upper lip, which suggests that such feature may represent a synapomorphy for the genus Pipa.

Four minute terminal lobes arise at the end of the fingers of Pipa arrabali by Stage II-5. These lobes occupy the entire tip surface, creating a quadripartite digital tip morphology (Fig. 2f). In subsequent stages there is an apparent fusion of the lobes into pairs, resulting in a dorsoventrally flattened fingertip. By Stage II-7, growth of the fingers leads to a slight separation of the lobes, with melanocytes clearly visible between them (Fig. 2f). By Stage II-11 the fingertip lobes are larger and exhibit a radial distribution. This peculiar modification of the adult fingertips is a distinctive characteristic of Pipa, with the exact shape and distribution of the lobes varying by species (Trueb and Cannatella 1986). For example, in the adult P. parva and juvenile $P$. myersi and $P$. pipa there are four asymmetrically distributed fingertip lobes; two of the lobes are fused in the adult P. myersi, creating a tripartite digital tip morphology. On the other hand, the adults of $P$. aspera, $P$. carvalhoi, $P$. pipa, and $P$. snethlageae exhibit an arrangement of the fingertip lobes similar to that described for $P$. arrabali. Unfortunately, further comparisons are hampered by the lack of information on the timing and process of development of these structures in the other Pipa species.
The body of a Stage II-1 embryo of Pipa arrabali lies on a large, wide-bore, coiled intestine filled with yolk; this condition persists until Stage II-4 (Figs. 1a, 1b, and 2c). As development proceeds, however, the yolk reserve slowly diminishes and the lumen of the intestine decreases to about half the size observed in previous stages. The initial length of the intestine is about one and a half coils by Stage II-1, it increases to three coils by Stage II-3, and shortens to about one and a quarter coils by Stage II-5. The axis of the coils is perpendicular to the body and the apex points downward. The concomitant development of the rectus abdominis completely conceals the intestine by Stage II-6 (i.e., the intestine becomes immersed within the pleuroperitoneal cavity). It is worth noting that, although the intestine of the embryo of $P$. arrabali is coiled, it is extremely short when compared to the seven or eight turns of the intestine of $P$. carvalhoi and $P$. parva free-living larvae (Sokol 1977). In the latter, the long, narrow-bore, highly coiled intestine implies a greater surface area available for digestion, whereas the shorter and wider intestine of $P$. arrabali only seems to fulfill a storage function. A wide intestine with a few coils has also been observed in, for example, embryos of Pseudophilautus sarasinorum (Bahir et al. 2005), a species that lacks free-living larvae. Its function in these embryos is unclear, although it could be related to yolk storage and absorption.

Embryos of Pipa arrabali have a muscular tail that, at full length, slightly exceeds the snout-vent length. In the first stages of Period II it consists of a muscular stem and a low membranous fin (including dorsal and ventral portions), with a round distal tip. The dorsal portion of the fin originates at about the area of the tail-body junction. The tail is both oriented to the left and right, and occasionally even folded under the body in older embryos. By Stage II-5 the tail muscles are weaker, and reabsorption is well under way by Stage II-6. At Stage II-7 the tail appears as a narrow and translucent piece, and by 
Stage II-11 it is extremely reduced or absent. The reduction of the muscles of the tail is synchronic with an increase in fin vascularization. By Stage 7-II, the muscular portion is almost absent whereas the fin size remains unchanged and the blood vessels are more conspicuous. Furthermore, the increase in fin vascularization is coincident with the reduction in size of the intestinal lumen and the incorporation of the gut inside the pleuroperitoneal cavity. We do not know if there is a correlation between gut size and tail vascularization; if it does indeed exist, perhaps it could indicate a role in nutrient absorption from the wall of the brood chamber once the yolk stored in the embryo's intestine is depleted. Fernandes et al. (2011) argued in favor of some type of interaction between embryonic and maternal tissues in P. carvalhoi. This suggestion was based on the presence of a large number of blood capillaries in the skin of the embryo, and a thin epidermis lacking a stratum corneum and a heavily vascularized dermis forming the walls of the brood chambers (Greven and Richter 2009, Fernandes et al. 2011). A vascularized tail may also suggest a role in gas exchange. A function of this kind has arguably been proposed for the highly vascularized tail in embryos of Eleutherodactylus coqui (Townsend and Stewart 1985) and Pseudophilautus (Bahir et al. 2005).

Pipa arrabali seems to exhibit a synchronous initial development of fore- and hind limbs. This pattern is similar to that reported for Discolossus pictus (Schlosser 2001), Eleutherodactylus coqui (Townsend and Stewart 1985), and Pseudis platensis (Fabrezi et al. 2009). This synchrony may be more widespread among anurans than usually reported. However, because in most free-swimming tadpoles forelimbs develop hidden inside an opaque gill chamber, their developmental morphology, prior to the external emergence through the skin that covers the gill chamber, do not constitute an informative feature that can be used in the staging process (e.g., Gosner 1960).
At Stage II-6, embryos of Pipa arrabali use their hands to cover the anterior region of the head (Fig. 1d) and by Stage II-10 the feet are also used in a similar way (Fig. 1e and 1f). By Stage II-11, however, neither hands nor feet are found in this position (Fig. 1g). We are not aware of any reports describing this peculiar position of the limbs neither in other pipids, nor in other anurans lacking free-swimming tadpoles such as Eleutherodactylus (Townsend and Stewart 1985, Callery et al. 2001, Elinson 2001), Arenophryne rotunda (Anstis et al. 2007), Myobatrachus gouldii (Anstis et al. 2007), Philautus silus (Kerney et al. 2007), and Gastrotheca (Del Pino and Escobar 1981). It is likely, however, that other species of Pipa that are born as froglets may display similar postures; this, in fact, was observed in embryos of P. pipa (Olívia G.S. Araújo, personal observation). We think that this posture may represent a protective reflex. Rabb and Snedigar (1960) reported embryos of $P$. pipa moving away from light. Likewise, the limb postures described herein may represent a response to the killing process.

This study provides staging criteria for embryos of Pipa arrabali as a basis for future research on this species, as well as on the other three species of Pipa that have no free living tadpoles. In addition, by correlating this table with the staging tables by Gosner (1960) and Nieuwkoop and Faber (1956) we offer a basis for comparison with species that develop as free swimming tadpoles. The availability of this staging table is crucial for understanding the mosaic of morphological and developmental features that characterize Pipidae in general, and Pipa in particular.

In order to understand better this mosaic of heterochronies, the comprehensive study of the internal morphology and ontogeny of Pipa arrabali would be relevant. Another important gap to be filled would be the descriptions of early embryonic development in this species (Period I). Furthermore, the observation of the development time of each stage would be very useful. 


\section{RESUMO}

Pipa é um gênero Neotropical de anuros que habitam ambientes aquáticos de água doce. Este gênero inclui quatro espécies que não possuem larvas livre-natantes (P. aspera, $P$. arrabali, $P$. pipa e $P$. snethlageae) e três que possuem girinos ( $P$. carvalhoi, $P$. myersi e $P$. parva). Tabelas de desenvolvimento, como a proposta por Nieuwkoop e Faber, podem ser úteis no caso de espécies de Pipa com girino. No entanto, para as outras espécies de Pipa, a determinação dos estágios por esta tabela ou por qualquer outra tabela já elaborada para anuros que não possuem girinos (e.g., Crinia nimbus, Eleutherodactylus coqui e Oreobates barituensis) é impossível. Usando embriões, juvenis e subadultos geramos uma tabela de desenvolvimento para $P$. arrabali, desde o momento em que surgem os primeiros indícios de formação dos membros até o nascimento, baseada em caracteres diagnósticos, como o comprimento rostro-cloacal; desenvolvimento, morfologia e a reabsorção da cauda; crescimento e diferenciação de membros anteriores e posteriores; desenvolvimento do intestino, do tubo cloacal e linhas laterais; posição do ângulo da boca em relação às narinas e aos olhos; e a cor dos indivíduos fixados. Com base nestas observações, discutimos algumas outras características notáveis (e.g., posição de mãos e pés). Também comparamos o padrão de desenvolvimento de $P$. arraba$l i$ com o de outras espécies (com e sem girinos).

Palavras-chave: Amphibia, Anura, desenvolvimento, morfologia, Pipidae.

\section{ACKNOWLEDGMENTS}

Olívia G.S. Araújo received a fellowship (\#2012/04443-1) and Célio F.B. Haddad received grants \#08/50928-1 and \#2013/50741-7 from Fundação de Amparo à Pesquisa do Estado de São Paulo (FAPESP). Célio F.B. Haddad and Hélio R. da Silva are research fellows of the Conselho Nacional de Desenvolvimento Científico e Tecnológico (CNPq). We thank Prof. Guarino R. Colli for allowing us access to specimens of Pipa arrabali in the Coleção Herpetológica da Universidade de Brasília (CHUnB). Three anonymous reviewers made helpful suggestions in a previous version of the manuscript.

\section{REFERENCES}

Anstis M, Roberts JD And Altig R. 2007. Direct development in two myobatrachid frogs, Arenophryne rotunda Tyler and Myobatrachus gouldii Gray, from western Australia. Rec West Aust Mus 23: 259-271.

BÁEZ AM AND PUGENER LA. 2003. Ontogeny of a new Palaeogene pipid frog from southern South America and xenopodinomorph evolution. Zool J Linn Soc 139: 439476.

BAHir MM, MeEgaskumbura M, MANAMEndraARACHCHI K, SCHNEIDER CJ AND PETHIYAGODA R. 2005. Reproduction and Terrrestrial direct development in Sri Lankan Shrub frogs (Ranidae: Rhacophorinae: Philautus). Raffles Bull Zool 12: 339-350.

BUCHACHER CO. 1993. Field studies on the small Surinam toad, Pipa arrabali, near Manaus, Brazil. Amphibia-Reptilia 14: 59-69.

CAllery EM, FAnG H And Elinson RP. 2001. Frogs without polliwogs: evolution of anuran direct development. BioEssays 23: 233-241.

DEL PINO EM AND ESCOBAR B. 1981. Embryonic stages of Gastrotheca riobambe (Fowler) during maternal incubation and comparison of development with other marsupial frogs. J Morphol 167: 277-295.

ELINSON RP. 2001. MINI-REVIEW Direct development: an alternative way to make a frog. Transplantation 95: 91-95.

FABREZI M, QUINZIO SI AND GOLDBERG J. 2009. Giant Tadpole and Delayed Metamorphosis of Pseudis platensis Gallardo, 1961 (Anura, Hylidae). J Herpetol 43: 228-243.

FERNANDES TL. ANTONIAZZI MM, SASSO-CERRI E, EGAMI ME, LIMA C, RODRIGUES MT AND JARED C. 2011. Carrying progeny on the back: reproduction in the Brazilian aquatic frog Pipa carvalhoi. South Am J Herpetol 6: 161-176.

FROST DR. 2015. Amphibian species of the world: an online reference. Version $6.0(08 / 04 / 2015)$. Available at: http:// research.amnh.org/herpetology/amphibia/index.html. American Museum of Natural History, New York, USA.

GARDA AA, BIAVATI GM AND CostA GC. 2006. Sexual dimorphism, female fertility, and diet of Pipa arrabali (Anura, Pipidae) in Serra do Cachimbo, Pará, Brazil. South Am J Herpetol 1: 20-24.

GOLDBERG J, CANDIOTI FVAND AKMENTIS M. 2012.Directdeveloping frogs: Ontogeny of Oreobates barituensis (Anura: Terrarana) and the development of a novel trait. Amphibia-Reptilia 33: 239-250.

GOSNER KL. 1960. A simplified table for staging anuran embryos and larvae with notes on identification. Herpetologica 16: 183-190.

GREVEN H AND RiCHTER S. 2009. Morphology of skin incubation in Pipa carvalhoi (Anura: Pipidae). J Morphol 270: 1311-1319.

HARDY JR JD. 1984. Frogs, egg teeth, and evolution: preliminary comments on egg teeth in the genus Eleutherodactylus. Bull Maryland Herpetol Soc 20: 1-11. 
Kerney R, MeEgaskumbura M, ManamendraARACHCHI K AND HANKEN J. 2007. Cranial ontogeny in Philautus silus (Anura: Ranidae: Rhacophorinae) reveals few similarities with other direct-developing anurans. J Morphol 268: 715-725.

MitCHELL N AND SWAIN R. 1996. Terrestrial development in the Tasmanian frog, Bryobatrachus nimbus (Anura: Myobatrachinae): larval development and a field staging table. Pap Proc R Soc Tasmania 130: 75-80.

NiEUWKOOP PD AND FABER J. 1956. Normal table of Xenopus laevis (Daudin): a systematical and chronological survey of the development from fertilized egg till the end of metamorphosis. North Holland Publ Co, Amsterdam, $260 \mathrm{p}$.

ORTON GL. 1943. The tadpole of Rinophrynus dorsalis. Occas Pap Mus Zool, Univ. Michigan 472: 1-7.

PARKER WK. 1876. On the structure and development of the skull in the Batrachia. Part II. Philos Trans R Soc Lond 166: 601-669.

POMBAL JR JP, SAZIMA I AND HADDAD CFB. 1994 Breeding behavior of the pumpkin toadlet, Brachycephalus ephippium (Brachycephalidae). J Herpetol 28: 516-519.

Pugener LA, MAglia AM AND TRUEB L. 2003. Revisiting the contribution of larval characters to an analysis of phylogenetic relationships of basal anurans. Zool J Linn Soc 139: 129-155.

RABB GB AND RABB MS. 1960. On the mating and egglaying behavior of the Surinam toad Pipa pipa. Copeia 1960: 271-276.

RABB GB AND SNEDIGAR R. 1960. Observations on breeding and development of the Surinam Toad, Pipa pipa. Copeia 1960: 40-44.
RIDEWOOD WG. 1897. On the structure and development of the hyobranchial skeleton and larynx in Xenopus and Pipa. Zool J Linn Soc 26: 53-128.

SCHLOSSER G. 2001. Using heterochrony plots to detect the dissociated coevolution of characters. J Exp Zool 291: 282-304.

SHELTON PM. 1970. The lateral line system at metamorphosis in Xenopus laevis (Daudin). J Embryol Exp Morphol 24: 511-524.

SOKOL OM. 1977. The free swimming Pipa larvae, with a review of pipid larvae and pipid phylogeny (Anura: Pipidae). J Morphol 154: 357-425.

TAYLOR AC AND KOLlRos JJ. 1946. Stages in the normal development of Rana pipiens larvae. Anat Rec 94: 7-23.

TAYLOR WR AND VAN DYKE GC. 1985. Revised procedures for staining and clearing small fishes and other vertebrates for bone and cartilage study. Cybium 9: 107-119.

TOWNSEND DS AND STEWART MM. 1985. Direct development in Eleutherodactylus coqui: a staging table. Copeia 1985: 423-436.

TRUEB L AND CANNATElla D. 1986. Systematics, morphology, and phylogeny of genus 27 Pipa (Anura: Pipidae). Herpetologica 42: 412-449.

TRueb L, Pugener LA AND MAGLiA AM. 2000. Ontogeny of the bizarre: an osteological description of Pipa pipa (Anura: Pipidae), with an account of skeletal development in the species. J Morphol 243: 75-104.

VITT LJ AND CALDWELL JP. 2014. Herpetology: an introductory biology of amphibians and reptiles. $4^{\text {th }}$ edition. Elsevier, London, $757 \mathrm{p}$.

WELLS KD. 2010. The ecology and behavior of amphibians. University of Chicago Press, Chicago, 1400 p.

APPENDIX

Specimens of Pipa arrabali examined.

\begin{tabular}{ccccccc}
\hline Species & Collection & Number & Stage & SVL (mm) & Tail (mm) & Preparation technique \\
\hline Pipa arrabali & CHUnB & $35027-\mathrm{D}$ & 2 & 5.5 & 4.5 & alcohol \\
Pipa arrabali & CHUnB & $35055-\mathrm{D}$ & 3 & 6 & 5.5 & alcohol \\
Pipa arrabali & CHUnB & $35000-\mathrm{D}$ & 4 & & & alcohol \\
Pipa arrabali & CHUnB & $35008-\mathrm{D}$ & 4 & & & alcohol \\
Pipa arrabali & CHUnB & $35045-\mathrm{D}$ & 5 & 8 & 7 & alcohol \\
Pipa arrabali & CHUnB & $35019-\mathrm{D}$ & 6 & 8 & 5 & alcohol \\
Pipa arrabali & CHUnB & $35030-\mathrm{D}$ & 7 & 7 & 6 & alcohol \\
Pipa arrabali & CHUnB & $35056-\mathrm{D}$ & 8 & 8 & 5 & alcohol \\
Pipa arrabali & CHUnB & $35051-\mathrm{D}$ & 9 & 10 & 2.5 & alcohol \\
Pipa arrabali & CHUnB & $35015-\mathrm{D}$ & 9 & 9 & 3.5 & alcohol \\
Pipa arrabali & CHUnB & $35014-\mathrm{D}$ & 9 & 9 & 2 & alcohol \\
Pipa arrabali & CHUnB & $35033-\mathrm{D}$ & 9 & 9 & 3 & alcohol \\
Pipa arrabali & CHUnB & $35013-\mathrm{D}$ & 10 & 10 & 3 & alcohol \\
Pipa arrabali & CHUnB & $35018-\mathrm{D}$ & 10 & & & alcohol \\
Pipa arrabali & CHUnB & $35053-\mathrm{D}$ & 11 & 10 & 0 & alcohol \\
Pipa arrabali & CHUnB & $35059-\mathrm{D}$ & 11 & & & alcohol \\
Pipa arrabali & CHUnB & $35050-\mathrm{C}$ & 11 & & & alcohol \\
Pipa arrabali & CHUnB & $35001-\mathrm{D}$ & juvenile & 10 & 0 & \\
\hline
\end{tabular}

